\title{
Studi Komperatif Analisis UU Transportasi Konvensional dan Peraturan Menteri Perhubungan Nomor 108 Tahun 2017 di Kota Medan
}

\author{
Sri Wahyuni*, Fitri Andriyani, Dedek Andriani, \& Liber Siagian \\ Jurusan Pendidikan Pancasila dan Kewarganegaraan, Fakultas Ilmu Sosial \\ Universitas Negeri Medan, Indonesia
}

\begin{abstract}
Abstrak
Penelitian ini dilakukan di Desa, Sei Kera Hilir I Jalan Pimpinan Nomor 70 Medan Perjuangan. Penulis ingin mengetahi tentang adakah dampak yang terjadi antara UU transportasi konvensional dan Peraturan Menteri Perhubungan Nomor 108 Tahun 2017 dalam kenyamanan berlalu lintas pada masyarakat di Desa, Sei Kera Hilir I Jalan Pimpinan Nomor 70 Medan Perjuangan. Metode penelitian ini dilakukan dengan menggunakan metode kuantitatif. Dimana penggalian data menggunakan instrumen angket, dan studi pustaka, pengambilan sampel diambil secara acak (random Sampling). Variabel penelitian ini adalah variabel tunggal. Berdasarkan penelitian, diketahui bahwa untuk mengakses transportasi online lebih mudah dibandingkan transportasi Konvensional yang dilihat dari angka persentasi lebih tinggi.

Kata Kunci : Transportasi Online, Transportasi Konvensional, Kenyamanan, Keamanan.
\end{abstract}

\begin{abstract}
This research was conducted in Village, Sei Kera Hilir I Road Leader Number 70 Medan struggle. Author is an impact between the Conventional Transportation Law and the minister of transportation number 108 year 2017 in the Village., Sei Kera Hilir I Road Leader number 70 Medan struggle. This research method is done by using quantitative method. Where the data is extracted using questionnaire. Interview and literature study. Sampling is taken at random (random sampling). Variable this research are variable single. Based on the research, it is known that access to online transportation seen from higter percentage figures.

Keyword: Transortation Oline, Conventional Transportation, Freshness, Security.
\end{abstract}

How to Cite: Wahyuni, S. Andriyani, F. Andriani, D. \& Siagian, L. (2018). Studi Komperatif Analisis UU Transportasi Konvensional dan Peraturan Menteri Perhubungan Nomor 108 Tahun 2017 di Kota Medan. Anthropos: Jurnal Antropologi Sosial dan Budaya, 4 (1): 86-91.

\begin{tabular}{ll}
\hline *Corresponding author: & ISSN 2460-4585 (Print) \\
E-mail: sriw8413@gmail.com & ISSN 2460-4593 (Online)
\end{tabular}




\section{PENDAHULUAN}

Kebutuhan transportasi merupakan kebutuhan keturunan akibat aktivitas ekonomi, sosial dan sebagainya. Penanganan permasalahan transportasi perkotaan harus dilakukan secara menyeluruh baik secara makro maupun mikro, yakni membuka titik-titik pertumbuhan ekonomi dan lembaga layanan masyarakat. Secara umum, system transportasi di Kota Medan masih belum memenuhi kriteria keberlanjutan yang ditandai dengan rendahnya kualitas angkutan umum, meningkatkan angka kecelakaan kemacetaan dijalan-jalan utama, meningkatkan polusi dan transportasi yang berbiaya tinggi.

Kondisi perkembangan Kota sangat erat kaitanya dengan pelayanan angkutan umumnya diera perkembangan transportasi yang makin modern, penataan angkutan umum tidak bergantung pada pendekatan potensi bangkitan dan tarikansemata sehingga pola perjalanan yang sifatnya subjektif dan karakteristik wilayah punya kontribusi yang besar terhadap kinerja angkutan umum.

Transportasi di Indonesia telah mempunyai 4 Undang-Undang sebagai payung hukumnya, yaitu : Undang-Undang Republik Indonesia Nomor 27 Tahun 2007 Tentang Perkeretaapian. UndangUndang Republik Indonesia Nomor 17 Tahun 2008 Tentang Pelayaran, Undang-Undang Republik Indonesia Nomor 1 Tahun 2000 Tentang Penerbangan Dan Undang-Undang Republik Indonesia Nomor 22 Tahun 2009 Tentang Lalu Lintas Angkutan Jalan Dan Peraturan Menteri Perhubungan Nomor 32 Tahun 2016 Tentang Penyelenggaraan Angkutan Orang Dengan Kendaraan Bermotor Umum Tidak Dalam Trayek Yang Telah Direvisi Menjadi Peraturan Menteri Perhubungan Nomor 108 Tahun 2017 Tentang Penyelenggaraan Angkutan Orang Dengan Kendaraan Bermotor Umum Tidak Dalam Trayek.

Teknologi digital kini juga telah dimanfaatkan untuk menunjang moda transportasi, smartphone sebagai sebuah perangkat kini dijadikan sebagai media pemesanan moda transportasi. Bahkan saat ini moda transportasi ojek sudah dapat diakses melalui teknologi aplikasi android yang tersedia di smartphone. Moda transportasi berbasis aplikasi muncul sebagai wujud dari perkembangan teknologi dan reaksi atas kelemahan penyedia jasa transportasi publik.
Kerumitan dalam transportasi publik bukan hanya menjadi masalah-masalah pemerintah, oprator saja melaikan juga masyarakat. Fenomena yang muncul akhir-akhir ini mengedepankan wajah transportasi publik yang kurang memberi kenyamanan, keamanan dan keterjangkauan dan masih mengesankan biaya sosial dan ekonomi tinggi. Hai ini berakibat pada pemikiran masyarakat secara tidak langsung untuk melakukan mobilitasnya.

Berdasarkan fenomena inilah, penulis tertarik meneliti dan mendeskripsikan secara detail tentang adakah dampak yang terjadi antara UU Transportasi Konvensional dan Peraturan Menteri Perhubungan Nomor 108 Tahun 2017 dalam kenyamanan berlalu lintas pada masyarakat di Desa, Sei Kera Hilir I Jalan Pimpinan Nomor 70.

\section{METODE PENELITIAN}

Lokasi penelitian ini dilakukan di Kecamatan Medan Perjuangan, berbatasan dengan Medan Timur di sebelah Barat, Medan Tembung dan Kabupaten Deli Serdang di Timur. Medan Area dan Medan Kota di Selatan, dan Medan Timur dan Kabupaten Deli Serdang di Utara. Penulis lebih memfokuskan penelitian ini di Desa, Sei Kera Hilir I Jalan Pimpinan Nomor 70 Medan Perjuangan.

Penelitian ini dilakukan dengan menggunakan metode Kuantitatif, dimana penggalian data menggunakan istrumen angket, wawancara dan studi pustaka. Pengambilan sampel diambil secara acak (random Sampling) sebesar 10\% dengan jumlah 60 orang. Variabel penelitian ini adalah variabel tunggal, jadi dari populasi 600 orang penelitian hanya mengambil sampel 60 orang untuk menjawab angket yang sudah dipersiapkan. Teknik pengumpulan data dilakukan dengan dokumentasi dan penyebaran angket.

\section{HASIL DAN PEMBAHASAN}

Tabel 1. Transportasi Online Maupun Transportasi Konvensional Sangat Mempengaruhi Kemacetan.

\begin{tabular}{|c|c|c|c|c|}
\hline No & Pilihan Jawaban & f & $\%$ & \multirow{6}{*}{$\begin{array}{l}N= \\
60\end{array}$} \\
\hline 1. & Sangat Setuju & 35 & $59 \%$ & \\
\hline 2. & Setuju & 23 & $38 \%$ & \\
\hline 3. & Tidak Setuju & 2 & $3 \%$ & \\
\hline 4. & Sangat Tidak Setuju & 0 & $0 \%$ & \\
\hline \multicolumn{2}{|c|}{ Jumlah } & 60 & $100 \%$ & \\
\hline
\end{tabular}

Sumber : Pengolahan Data Premier

Data pada tabel di atas menunjukkan bahwa dari 60 orang responden yang mempengaruhi 
kemacetan. Dari hasil presentase yang telah diperoleh dapat disimpulkan bahwa masyarakat sangat setuju bahwa kehadiran transportasi online maupun transportasi konvensional sangat mempengaruhi kemacetan.

Tabel 2. UU Nomor 22 Tahun 29 Dan Peraturan Menteri Perhubungan No 1082017 Tentang Lalu Lintas Dan Angkutan Jalan Lebih ditingkatkan lagi.

\begin{tabular}{|c|c|c|c|c|}
\hline No & Pilihan Jawaban & $\mathbf{f}$ & $\%$ & \multirow{6}{*}{$\begin{array}{l}N= \\
60\end{array}$} \\
\hline 1. & Sangat Setuju & 29 & $49 \%$ & \\
\hline 2. & Setuju & 29 & $48 \%$ & \\
\hline 3. & Tidak Setuju & 2 & $3 \%$ & \\
\hline 4. & Sangat Tidak Setuju & 0 & $0 \%$ & \\
\hline \multicolumn{2}{|c|}{ Jumlah } & 60 & $100 \%$ & \\
\hline
\end{tabular}

Sumber : Pengolahan Data Premier

Data pada tabel di atas menunjukkan bahwa dari 60 responden dapat disimpulkan bahwa masyarakat sangat setuju bahwa UU Nomor 22 Tahun 29 dan Peraturan Menteri Perhubungan No 108 Tahun 2017 Tentang Lalu Lintas Dan Angkutan Jalan lebih ditingkatkan lagi.

Tabel 3. Pelayanan Yang Diberikan Transportasi Online Lebih Memadai Dibandingkan Transportasi Konvensional.

\begin{tabular}{|c|c|c|c|c|}
\hline No & Pilihan Jawaban & f & $\%$ & \multirow{7}{*}{$\begin{array}{l}N= \\
60\end{array}$} \\
\hline 1. & Sangat Setuju & 29 & & \\
\hline & & & $49 \%$ & \\
\hline 2. & Setuju & 28 & $46 \%$ & \\
\hline 3. & Tidak Setuju & 2 & $3 \%$ & \\
\hline 4. & Sangat Tidak Setuju & 1 & $2 \%$ & \\
\hline \multicolumn{2}{|c|}{ Jumlah } & 60 & $100 \%$ & \\
\hline
\end{tabular}

Sumber : Pengolahan Data Premier

Hasil yang diperoleh dengan melihat presentase responden yang menjawab sangat setuju bahwa pelayanan yang diberikan transportasi online lebih memadai dibandingkan transportasi konvensional. Dari hasil presentase yang telah diperoleh dapat disimpulkan bahwa masyarakat sangat setuju terhadap pelayanan yang diberikan transportasi online lebih memadai dibandingkan transportasi konvensional.

Tabel 4. Tingkat Kenyamanan Dalam Berkendara Transportasi Online Lebih Terjaga Kenyamananya Dibandingkan Transportasi Konvensional.

\begin{tabular}{|c|c|c|c|c|}
\hline No & Pilihan Jawaban & f & $\%$ & \multirow{6}{*}{$\begin{array}{l}N= \\
60\end{array}$} \\
\hline 1. & Sangat Setuju & 26 & $43 \%$ & \\
\hline 2. & Setuju & 29 & $49 \%$ & \\
\hline 3. & Tidak Setuju & 4 & $6 \%$ & \\
\hline 4. & Sangat Tidak Setuju & 1 & $2 \%$ & \\
\hline \multicolumn{2}{|c|}{ Jumlah } & 60 & $100 \%$ & \\
\hline
\end{tabular}

Sumber : Pengolahan Data Premier

Data pada tabel di atas menunjukkan bahwa dari 60 orang responden yang akan mengetahui tingkat kenyamanan dalam berkendara transportasi online lebih terjaga dibandingkan transportasi konvensional. Dari hasil presentase yang telah diperoleh dapat disimpulkan bahwa masyarakat setuju terhadap tingkat kenyamanan dalam berkendara transportasi online lebih terjaga dibandingkan transportasi konvensional.

Tabel 5. Trasportasi Online Lebih Aman Digunakan Dibandingkan Transportasi Konvensional

\begin{tabular}{|c|c|c|c|c|}
\hline No & Pilihan Jawaban & f & $\%$ & \\
\hline 1. & Sangat Setuju & 14 & $24 \%$ & \\
\hline 2. & Setuju & 33 & $55 \%$ & \\
\hline 3. & Tidak Setuju & 11 & $18 \%$ & $\mathbf{N}=$ \\
\hline 4. & Sangat Tidak Setuju & 2 & $3 \%$ & \\
\hline \multicolumn{2}{|c|}{ Jumlah } & 60 & $100 \%$ & \\
\hline
\end{tabular}

Sumber : Pengolahan Data Premier

Data pada tabel di atas menunjukkan bahwa dari 60 orang responden yang akan mengetahui transporatsi online lebih aman digunakan dibandingkan dengan trasnsportasi konvensional. Dari hasil presentase yang telah diperoleh dapat disimpulkan bahwa masyarakat setuju terhadap transporatsi online lebih aman digunakan dibandingkan dengan trasnsportasi konvensional.

Tabel 6. Dengan Adanya Transportasi Online Sekarang Ini Mampu Menciptakan Lapangan Pekerjaan.

\begin{tabular}{|l|l|l|l|l|}
\hline No & Pilihan Jawaban & f & $\mathbf{\%}$ & \\
\hline 1. & Sangat Setuju & 17 & $29 \%$ & \\
\hline 2. & Setuju & 35 & $58 \%$ & \multirow{2}{*}{$\mathbf{N}=$} \\
\hline 3. & Tidak Setuju & 8 & $13 \%$ & $\mathbf{6 0}$ \\
\hline 4. & Sangat Tidak Setuju & 0 & $0 \%$ & \\
\hline \multicolumn{2}{|l|}{ Jumlah } & 60 & $100 \%$ & \\
\hline
\end{tabular}

Sumber : Pengolahan Data Premier

Data pada tabel di atas menunjukkan bahwa dari 60 orang responden yang akan mengetahui transporatsi online sekarang ini mampu menciptakan lapangan pekerjaan. Dari hasil presentase yang telah diperoleh dapat disimpulkan bahwa masyarakat setuju terhadap transporatsi online sekarang ini mampu menciptakan lapangan pekerjaan.

Tabel 7. Menggunakan Transportasi Konvensional Lebih Terjaga Keselamatan Dijalan Dibandingkan Transportasi

\begin{tabular}{|l|l|l|l|l|}
\hline No & Pilihan Jawaban & f & $\mathbf{\%}$ & \\
\hline 1. & Sangat Setuju & 10 & $17 \%$ & \\
\hline 2. & Setuju & 26 & $43 \%$ & \multirow{2}{*}{ N = } \\
\hline 3. & Tidak Setuju & 19 & $32 \%$ & $\mathbf{6 0}$ \\
\cline { 1 - 3 } 4. & Sangat Tidak Setuju & 5 & $2 \%$ & \\
\cline { 1 - 3 } \multicolumn{2}{|l|}{ Jumlah } & 60 & $100 \%$ & \\
\hline
\end{tabular}

Sumber : Pengolahan Data Premier 
Data pada tabel di atas menunjukkan bahwa dari 60 orang responden yang akan mengetahui menggunakan transporatsi konvensional lebih terjaga keselamatan dijalan dibading transportasi online. Dari hasil presentase yang telah diperoleh dapat disimpulkan bahwa masyarakat setuju terhadap menggunakan transporatsi konvensional lebih terjaga keselamatan dijalan dibading transportasi online.

Tabel 8. Dengan Memakai Helm dalam Menggunakan Transportasi Online Merupakan Keselamatan Untuk

$$
\text { Anda di Jalan }
$$

\begin{tabular}{|c|c|c|c|c|}
\hline No & Pilihan Jawaban & $\mathbf{F}$ & $\%$ & \multirow{6}{*}{$\begin{array}{l}N= \\
60\end{array}$} \\
\hline 1. & Sangat Setuju & 30 & $50 \%$ & \\
\hline 2. & Setuju & 26 & $43 \%$ & \\
\hline 3. & Tidak Setuju & 3 & $5 \%$ & \\
\hline 4. & Sangat Tidak Setuju & 1 & $2 \%$ & \\
\hline \multicolumn{2}{|c|}{ Jumlah } & 60 & $100 \%$ & \\
\hline
\end{tabular}

Sumber : Pengolahan Data Premier

Data pada tabel di atas menunjukkan bahwa dari 60 orang responden yang akan mengetahui dengan memakai helmmenggunakan trasnportasi olnine merupakan keselamatan unttuk dijalan. Dari hasil presentase yang telah diperoleh dapat disimpulkan bahwa masyarakat sangat setuju terhadap dengan memakai helmmenggunakan trasnportasi olnine merupakan keselamatan unttuk dijalan.

Tabel 9. Untuk Tarif Menggunakan Transportasi Lebih Setuju Tarif Yang Berlaku Di Transportasi Online Di Banding Dengan Transportasi Konvensional

\begin{tabular}{|c|c|c|c|c|}
\hline No & Pilihan Jawaban & f & $\%$ & \multirow{6}{*}{$\begin{array}{l}N= \\
60\end{array}$} \\
\hline 1. & Sangat Setuju & 16 & $27 \%$ & \\
\hline 2. & Setuju & 28 & $46 \%$ & \\
\hline 3. & Tidak Setuju & 13 & $22 \%$ & \\
\hline 4. & Sangat Tidak Setuju & 3 & $5 \%$ & \\
\hline \multicolumn{2}{|c|}{ Jum } & 60 & $100 \%$ & \\
\hline
\end{tabular}

Sumber : Pengolahan Data Premier

Data pada tabel di atas menunjukkan bahwa dari 60 orang responden yang akan mengetahui untuk tarif mengunakan transportasi lebih setuju dengan tarif yang berlaku di transportasi online dibandingkan dengan transportasi konvensional. Dari hasil presentase yang telah diperoleh dapat disimpulkan bahwa masyarakat setuju terhadap untuk tarif mengunakan transportasi lebih setuju dengan tarif yang berlaku di transportasi online dibandingkan dengan transportasi konvensional.
Tabel 10. Aplikasi Transportasi Online Menyediakan Layanan Dengan Cepat, Tepat Untuk Menangani Permasalahan Contoh : Ketika Pengguna Lupa Password, Aplikasi Menyediakan Cara Untuk Mengubah Password)

\begin{tabular}{|l|l|l|l|l|}
\hline No & Pilihan Jawaban & f & $\mathbf{\%}$ & \\
\hline 1. & Sangat Setuju & 19 & $32 \%$ & \\
\hline 2. & Setuju & 27 & $45 \%$ & \multirow{2}{*}{$\mathbf{N}=$} \\
\hline 3. & Tidak Setuju & 12 & $20 \%$ & \multirow{6}{6}{$\mathbf{6 0}$} \\
\cline { 1 - 3 }. & Sangat Tidak Setuju & 2 & $3 \%$ & \\
\cline { 1 - 3 } Jumlah & 60 & $100 \%$ & \\
\hline
\end{tabular}

Sumber : Pengolahan Data Premier

Data pada tabel di atas menunjukkan bahwa dari 60 orang responden dapat disimpulkan bahwa masyarakat setuju terhadap aplikasi transportasi online menyediakan layanan dengan cepat dan tepat untuk menangani permasalahan contoh: ketika pengguna lupa password, aplikasi menyediakan cara untuk mengubah password.

Tabel 11. Aplikasi Transportasi Online Memberikan Layanan Sesuai Dengan Pemahaman Saya. (Contoh: Ketika Saya Memesan Layanan Transportasi, Saya Mendapatkan Perkiraan Harga Dan Jarak)

\begin{tabular}{|c|c|c|c|c|}
\hline No & Pilihan Jawaban & $\mathbf{f}$ & $\%$ & \multirow{6}{*}{$\begin{array}{l}N= \\
60\end{array}$} \\
\hline 1. & Sangat Setuju & 15 & $26 \%$ & \\
\hline 2. & Setuju & 32 & $53 \%$ & \\
\hline 3. & Tidak Setuju & 9 & $15 \%$ & \\
\hline 4. & Sangat Tidak Setuju & 4 & $6 \%$ & \\
\hline \multicolumn{2}{|c|}{ Jumlah } & 60 & $100 \%$ & \\
\hline
\end{tabular}

Sumber : Pengolahan Data Premier

Data pada tabel di atas menunjukkan bahwa dari 60 orang responden dapat disimpulkan bahwa masyarakat setuju terhadap aplikasi transportasi online memberikan layanan sesuai dengan pemahaman saya. (contoh: ketika saya memesan layanan transportasi, saya mendapatkan perkiraan harga dan jarak).

Tabel 12. Tarnsportasi Online Dapat Digunakan Dengan

\begin{tabular}{|c|c|c|c|c|}
\hline \multicolumn{5}{|c|}{ Mudah } \\
\hline No & Pilihan Jawaban & f & $\%$ & \multirow{6}{*}{$N=60$} \\
\hline 1. & Sangat Setuju & 23 & $38 \%$ & \\
\hline 2. & Setuju & 34 & $57 \%$ & \\
\hline 3. & Tidak Setuju & 3 & $5 \%$ & \\
\hline 4. & Sangat Tidak Setuju & 0 & $0 \%$ & \\
\hline \multicolumn{2}{|c|}{ Jumlah } & 60 & $100 \%$ & \\
\hline
\end{tabular}

Sumber : Pengolahan Data Premier

Data pada tabel di atas menunjukkan bahwa dari 60 orang responden yang akan mengetahui tarnsportasi online dapat digunakan dengan mudah. Dari hasil presentase yang telah diperoleh dapat disimpulkan bahwa masyarakat setuju terhadap tarnsportasi online dapat digunakan dengan mudah. 
Tabel 13. Aplikasi Transportasi Online Menyediakan Layanan Yang Konsisten, Dapat Diandalkan, Akurat (Sesuai Dengan Layanan Yang Dijanjikan Pada Aplikasi).

\begin{tabular}{|c|c|c|c|c|}
\hline No & Pilihan Jawaban & $\mathbf{f}$ & $\%$ & \multirow{6}{*}{$N=60$} \\
\hline 1. & Sangat Setuju & 18 & $30 \%$ & \\
\hline 2. & Setuju & 30 & $50 \%$ & \\
\hline 3. & Tidak Setuju & 9 & $15 \%$ & \\
\hline 4. & Sangat Tidak Setuju & 3 & $5 \%$ & \\
\hline \multicolumn{2}{|c|}{ Jumlah } & 60 & $100 \%$ & \\
\hline
\end{tabular}

Sumber : Pengolahan Data Premier

Data pada tabel di atas menunjukkan bahwa

dari 60 orang responden yang akan mengetahui aplikasi transportasi online menyediakan layanan yang konsisten, dapat diandalkan, akurat (sesuai dengan layanan yang dijanjikan pada aplikasi). Dari hasil presentase yang telah diperoleh dapat disimpulkan bahwa masyarakat setuju terhadap aplikasi transportasi online menyediakan layanan yang konsisten, dapat diandalkan, akurat (sesuai dengan layanan yang dijanjikan pada aplikasi).

Tabel 14. Penampilan Aplikasi Transportasi Online Sangat Bagus Dan Mudah Dimengerti

\begin{tabular}{|c|c|c|c|c|}
\hline No & Pilihan Jawaban & f & $\%$ & \multirow{6}{*}{$N=60$} \\
\hline 1. & Sangat Setuju & 21 & $35 \%$ & \\
\hline 2. & Setuju & 33 & $55 \%$ & \\
\hline 3. & Tidak Setuju & 4 & $7 \%$ & \\
\hline 4. & Sangat Tidak Setuju & 2 & $3 \%$ & \\
\hline \multicolumn{2}{|c|}{ Jumlah } & 60 & $100 \%$ & \\
\hline
\end{tabular}

Sumber : Pengolahan Data Premier

Data pada tabel di atas menunjukkan bahwa dari 60 orang responden yang akan mengetahui penampilan aplikasi transportasi online sangat bagus dan mudah dimengerti. Dari hasil presentase yang telah diperoleh dapat disimpulkan bahwa masyarakat setuju penampilan aplikasi transportasi online sangat bagus dan mudah dimengerti.

Tabel 15. Transportasi Online Sangat Mudah Diakses Melalaui Aplikasi Dibandingan Transportasi Konvensional Yang Harus Diangses Dengan Kita Mendatangi Pangkalan Transpotasi Konvensional

\begin{tabular}{|c|c|c|c|c|}
\hline No & Pilihan Jawaban & f & $\%$ & \multirow{6}{*}{$N=60$} \\
\hline 1. & Sangat Setuju & 37 & $62 \%$ & \\
\hline 2. & Setuju & 21 & $35 \%$ & \\
\hline 3. & Tidak Setuju & 2 & $3 \%$ & \\
\hline 4. & Sangat Tidak Setuju & 0 & $0 \%$ & \\
\hline \multicolumn{2}{|c|}{ Jumlah } & 60 & $100 \%$ & \\
\hline
\end{tabular}

Sumber : Pengolahan Data Premier

Data pada tabel diatas menunjukkan bahwa dari 60 orang responden sangat setuju transportasi online sangat mudah diakses melalaui aplikasi dibandingan transportasi konvensional yang harus diangses dengan kita mendatangi pangkalan transpotasi konvensional.

\section{SIMPULAN}

Berdasarkan Hasil penelitian Studi Komperatif Analisis UU Transportasi konvensional dan Peraturan Menteri Nomor 108 Tahun 2017 Di Kota Medan, yang telah dilakukan, maka dapat disimpulkan bahwa dampak dari adanya transportasi online sangat mempengaruhi kemacetan hampir (59\%) yang setuju bahwa semakin adanya transportasi online kemacetan makin bertambah dikarena, pengemudi transportasi online sering parkir dibaku jalan. Selanjutnya Dari hasil presentase yang telah diperoleh dapat disimpulkan bahwa masyarakat sangat setuju bahwa UU Nomor 22 Tahun 29 dan Peraturan Mentri Perhubungan tentang lalu lintas dan angkutan jalan lebih ditingkatkan lagi dan para pengemudi transportasi online maupun konvensional harus juga mengentahui UU dan Peraturan Menteri Perhubungan yang telah berlaku, serta sebagian masyarakat setuju terhadap transporatsi online lebih aman digunakan dibandingkan dengan trasnsportasi konvensional. Selanjutnya Dari hasil presentase yang telah diperoleh dapat disimpulkan bahwa masyarakat setuju menggunakan transporatsi konvensional lebih terjaga keselamatan dijalan dibading transportasi online. jadi hasil dari hasil penelitian ini bahwa sebagian dari masyarakat menyetujui munculnya transportasi online dan transportasi online juga menjanjikan lapangan pekerjaan.

\section{DAFTAR PUSTAKA}

Adisasmita, R. (2010). Dasar-Dasar Ekonomi Transportasi. Yogyakarta: Penerbit Graha Ilmu.

Amajida, D.F. (2016). Kreativitas Digital Dalam Masyarakat Risiko Perkotaan. Studi Tentang Ojek Online Gojek diJakarta. Dalam Jurnal Volume 46 Nomor 1

Bustomi, F. (2013). Evaluasi Kinerja Angkutan Umum Trayek Lyn Merah Jurusan Sukodadi-Paciran Kabupaten Lamongan Berdasarkan Kepuasan Pelayanan. Dalam Jurnal Teknika Vol. 5 No 2.

Gunardo. (2014). Geografi Transportasi. Yogyakarta : Penerbit Ombak (Anggota IKAPI).

Hairulsyah. (2006). Kajian Tentang Transportasi di Kota Medan dan Permasalahannya. Dalam Jurnal Perencanaan dan Pengembangan Wilayah Wahana Hijau. Volume 1 Nomor 3. 
Pinayungan, J. Kusmanto, H. \& Isnaini. (2018). Implementasi Peraturan Menteri Perhubungan Republik Indonesia Tentang Standar Keselamatan Lalu Lintas Dan Angkutan Jalan. Jurnal Administrasi Publik. 8 (1): 108-123.

Prihatin, B.R. (2016). Dampak sosial Transportasi Berbasis Online. Vol. VIII, No. 07/I/P3DI/April.
Salim, A. (2000). Manajemen Transportai. Jakarta : PT RajaGrafindo Persada.

Sulistyowati. (2016). Pengaruh Kualitas Pelayanan Transportasi Online Gojek Terhadap Kepuasan Pelanggan Pada mahasiswa dan Administrasi Niaga Politeknik Negeri Jakarta. Epigram Vol. 13 No 2. 